\title{
SMALL SCALE HOME DRYING OF INDIGENOUS FISH SPECIES IN URBAN HIGH-RISES AT DHAKA METRO
}

\author{
Samia Farhana Sobhan* and M. Niamul Naser \\ Department of Zoology, University of Dhaka, Dhaka-1000, Bangladesh
}

\begin{abstract}
Drying is one of the common and ancient methods of fish preservation and is generally done in a wide range of open space. This study attempt to evaluate fish drying method at high-rise urban households with three small indigenous fishes namely Mola (Amblypharyngodon mola), Chapila (Gudusia chapra) and Lal Khailsha (Trichogaster lalius). Fishes were dried at high-rise indoor veranda and outdoor rooftop conditions. The dry weight of Mola, Chapila and Lal Khailsha fishes were $70 \%, 69.5 \%$ and $72 \%$ in indoor condition and $71.1 \%$, $70.5 \%$ and $73 \%$ in outdoor condition. The differences of drying capacity between the indoor and outdoor dried fishes were none $(\mathrm{p}<0.05)$, thus, the both drying methods are feasible for the urban lifestyle. In dry state, the moisture level in Mola, Chapila and Lal Khailsha were $6.45 \%, 7.89 \%$ and $7.82 \%$ whereas, the protein level were $66.51 \%, 72.26 \%$ and $62.02 \%$ respectively. The ash value found in the respective fishes was $10.05 \%, 12.18 \%$ and $16.07 \%$ and the amount of total fat was $11.14 \%, 11.28 \%$ and $12.32 \%$ respectively. The protein and moisture values showed an inverse relationship between the indoor and outdoor condition. The preference analysis of dried fish was found to be highly (100\%) accepted among the dry fish-eating consumers from Chittagong, Lakhimpur, Mymensingh, Rangpur, Bandarban, Pabna and Sylhet districts. On the contrary, in case of the consumers of Barisal and Chandpur districts, the level of acceptance was none $(0 \%)$, whereas the consumers of Kushtia district have accepted the dry fish moderately $(60 \%)$.

Key words: Dry fish, Home made, Highrise, Small indigenous fish, feasibility, quality, acceptance
\end{abstract}

\section{INTRODUCTION}

Drying is one of the most important methods of preserving fish throughout the world though it is regarded as a traditional, even primitive method of fish preservation in many developed countries. It is still of vital importance in the less developed region of the world and will remain so far, a long time to come (Waterman, 1976). About $20 \%$ of the catch of the world is preserved by sun drying and consumed in the domestic market (Coulter and Disney, 1987). Considering different drying methods, open

*Author for Corresponding: <samia.f.sobhan@gmail.com>

(C)2021 Zoological Society of Bangladesh DOI: https://doi.org/10.3329/bjz.v49i1.53687 
sun drying is one of the most common, low cost and ancient method of fish preservation (Zaitsev et al., 1969). The products play an important role particularly in providing nutrients to the all categories of people throughout the world including Bangladesh. But to prevent the flies and insect infestation of fish during drying, pesticides or chemicals is randomly used (Anwar, 1991), which are very harmful for human health and reduce the food quality of the dry fishes. Moreover, commercial drying of fish is done in a wide range of open space in floor or in bamboo platforms. In large metro city like Dhaka, people live in small houses like apartments, hostels or even in shed. Thus, small scale house drying to produce dry fish in urban environment, could meet the family demand and aid in quality preservation. The present study was an attempt to evaluate small scale fish drying at household level; matching the urban lifestyle. Innovative approach has been taken to study the feasibility of small sized dryer to produce dry fish in limited space. Fishes had been dried both in indoor (veranda) and outdoor (roof) conditions. In that case, no harmful pesticides or chemicals have been used. On the other hand, the proximate analysis of the product and consumer's acceptance have also been accessed.

\section{MATERIAL AND METHODS}

Drying of fish: After collecting and cleaning the three types of fishes, Mola (Amblypharyngodon mola), Chapila (Gudusia chapra) and Lal Khailsha (Trichogaster lalius), the weight of the fishes was taken with the help of a digital balance meter and then placed in traditional bamboo trays (Dala) randomly. The initial weight of Mola, Chapila and Lal Khailsha was 90g, 95g and 100g respectively. The dryers were covered with nets containing small meshed size to protect the fishes from flies and other insect infestation and glass thermometer was placed in each tray to record the temperature. The duration of the study was six days from 24.07.2020 to 29.07.2020. In both indoor and outdoor drying, daily record of weight after drying was taken in gram (Melter, USA, sensitivity $0.1 \mathrm{~g}$ ), while the temperature was measured in degree celsius and recorded at a specific time (at 2p.m.) every day.

A high raised twelve storied apartment was considered as the location for drying the fishes, whereby fishes were dried at the veranda of the $7^{\text {th }}$ floor for indoor drying and at the roof of the apartment for outdoor drying. A rope hanger was used to place the bamboo trays inside after drying every day, to prevent the fishes from any damage or ant assault. This technique was very beneficial in regard to save the fishes. The rope hanger was hanged from the roof of the veranda. 
Proximal analysis: The fishes were evaluated for quality and nutritional assessment in the Meat, Poultry and Slaughter House Waste Research Section of the Institute of Food, Science and Technology (IFST) of Bangladesh Council of Scientific and Industrial Research (BCSIR). In this case, fish have been analyzed for assessment in both indoor and outdoor dried condition whereas moisture and ash have been measured as considered parameter. To estimate ash, gravimetric
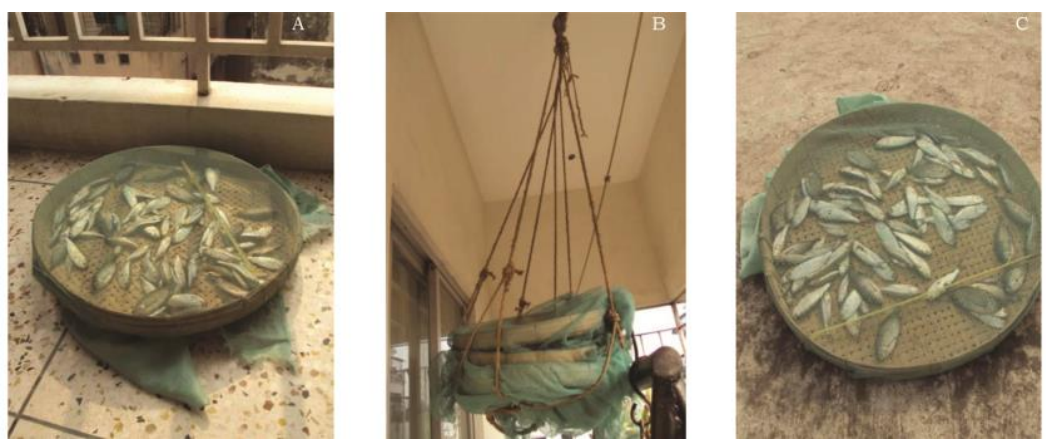

Fig.1. (a) Indoor drying of fish in the veranda. (b) Fish hanged in rope hanger to be protected. (c) Outdoor drying of fish at the rooftop.

method had been used where, the sample was heated in gas burner for 2 hours and then placed in $550^{\circ} \mathrm{C}$ in furnace for around 12 hours. On the other hand, the sample were placed in oven with $150^{\circ} \mathrm{C}$ overnight to estimate the moisture content. In both cases, to assess ash and moisture, the sample was transferred in a desiccator by closing the desiccator to allow the sample to cool. Then the final weight was taken.

Nutritional analysis: Protein and fat had been assessed for appraising nutrition value. In this regard, Micro-Kjeldahl's method and chloroform methanol extraction technique had been used for protein and fat estimation.

Consumer preferences: Test analysis was another portion of the work where the experimental dried fishes were provided to consumers of different regions to evaluate the test. In this regard, consumers of ten districts (Chittagong, Chandpur, Faridpur, Barisal, Mymensingh, Rangpur, Bandarban, Kushtia, Pabna and Sylhet) had been selected to analyze their preferences. Marking of fish have been done at a scale of ten, where better the test of fish highest ten the marking and marking nearest of zero for the rejection. Dependency (on dry fish) based preference of the consumer's along with their cultural background and fish-eating habit had been considered in this regard, in case of marking the studied fishes by the consumers. 


\section{RESULTS AND DISCUSSION}

While producing dried fish, the changing pattern in weight was observed for six consecutive days from 24.07.2020 to 29.07.2020. The rate of decrease in weights was rapid at the initial stage and then turned low and finally became steady. In this regard, the initial weight of Mola, Chapila and Lal Khailsha were $90 \mathrm{~g}, 95 \mathrm{~g}$ and $100 \mathrm{~g}$ respectively, the recorded temperature varied from $34^{\circ} \mathrm{C}$ $37^{\circ} \mathrm{C}$ whereas humidity varied from $61 \%$ to $69 \%$ in both indoor and outdoor setup.

In case of indoor drying, the weight turned down in case of Mola, Chapila and Lal Khailsha into $27 \mathrm{~g}, 29 \mathrm{~g}$ and $28 \mathrm{~g}$ respectively. Thus, the weight loss or moisture loss was recorded $70 \%, 69.5 \%$ and $72 \%$ in the corresponding fishes (Table 1).

Table 1. Weight loss during the indoor drying of Mola, Chapila and Lal Khailsha

\begin{tabular}{|c|c|c|c|c|c|c|c|}
\hline Name of fish & Day-1 & Day-2 & Day-3 & Day- 4 & Day-5 & Day-6 & $\begin{array}{c}\text { Percentage of } \\
\text { Drying in 5-6 } \\
\text { days }\end{array}$ \\
\hline Mola (g) & 90 & 62 & 48 & 30 & 27 & 27 & $70.0 \%$ \\
\hline Chapila (g) & 95 & 67 & 50 & 32 & 29 & 29 & $69.5 \%$ \\
\hline Lal Khailsha (g) & 100 & 64 & 48 & 31 & 28 & 28 & $\begin{array}{c}72.0 \% \\
\text { Average } \pm \text { SD }\end{array}$ \\
\hline Air Temperature $\left({ }^{\circ} \mathrm{C}\right)$ & 36 & 35 & 37 & 37 & 35 & 34 & $35.67 \pm 1.21$ \\
\hline Morning & 69 & 62 & 67 & 69 & 69 & 69 & $68.67 \pm 0.82$ \\
\hline Humidity Evening & 69 & 62 & 61 & 62 & 63 & 64 & $62.33 \pm 1.03$ \\
\hline
\end{tabular}

On the contrary, considering the same consecutive six days in outdoor condition it was found that, the weight of Mola, Chapila and Lal Khailsha became fixed at $26 \mathrm{~g}, 28 \mathrm{~g}$ and $27 \mathrm{~g}$ respectively. The changing percentage of weight loss after sun drying of the three fishes were $71.11 \%, 70.53 \%$ and $73 \%$ correspondingly (Table 2).

Table 2. Weight loss during the outdoor drying of Mola, Chapila and Lal Khailsha

\begin{tabular}{|c|c|c|c|c|c|c|c|}
\hline Name of fish & Day-1 & Day-2 & Day-3 & Day-4 & Day-5 & Day-6 & $\begin{array}{l}\text { Percentage } \\
\text { of Drying in } \\
5-6 \text { days }\end{array}$ \\
\hline Mola (g) & 90 & 60 & 47 & 31 & 26 & 26 & $71.1 \%$ \\
\hline Chapila (g) & 95 & 69 & 52 & 30 & 28 & 28 & $70.5 \%$ \\
\hline Lal Khailsha (g) & 100 & 62 & 49 & 30 & 27 & 27 & $\begin{array}{l}73.0 \% \\
\text { Average } \pm \mathrm{SD}\end{array}$ \\
\hline $\begin{array}{l}\text { Air Temperature } \\
\left({ }^{\circ} \mathrm{C}\right)\end{array}$ & 36 & 35 & 37 & 37 & 35 & 34 & $35.67 \pm 1.21$ \\
\hline Humidity & 69 & 69 & 67 & 69 & 69 & 69 & $68.67 \pm 0.82$ \\
\hline $\begin{array}{l}\text { Morning } \\
\text { Evening }\end{array}$ & 62 & 62 & 61 & 62 & 63 & 64 & $62.33 \pm 1.03$ \\
\hline
\end{tabular}


While analyzing the two set up, it is observed that, the percentage weight loss of Mola is $71.11 \%$ in outdoor drying process which is $70 \%$ in case of indoor drying condition, whereas, the weight loss is $70.53 \%$ in outdoor and $69.5 \%$ in indoor state in case of Chapila fish and for Lal Khailsha species, $73 \%$ and $72 \%$ weight loss occurred in case of outdoor and indoor drying condition respectively. In this regard, to estimate the difference of moisture content between indoor and outdoor dried fish T-Test had been applied. It was found that, the t-value of Mola, Chapila and Lal Khailsha is $0.05(\mathrm{p}<0.5), 0(\mathrm{p}<0.5)$, and $0.04(\mathrm{p}<0.5)$ respectively. Considering the value, it can be stated that, there is no significance difference in moisture between the indoor and outdoor drying method.

Proximate analysis, in biochemical study of indoor dried fish (Table 3), it was found that, the moisture content varied from $10.59 \%$ to $11.89 \%$, whereas the value of protein is comparatively high, ranging from $60.97 \%$ to $71.26 \%$. Besides the protein and moisture value, the obtained fat and ash content of those fishes ranged from $10.17 \%$ to $10.98 \%$ and $10.02 \%$ to $15.89 \%$ respectively. On the other hand, at outdoor drying the values ranged from $10.20 \%$ to $11.97 \%$ moisture, $62.02 \%$ to $72.26 \%$ protein, $11.14 \%$ to $12.32 \%$ fat and $10.05 \%$ to $16.07 \%$ ash.

Table 3. Proximate composition of the studied fishes

\begin{tabular}{lcccccccc}
\hline & \multicolumn{2}{c}{ Moisture (\%) } & \multicolumn{2}{c}{ Ash (\%) } & \multicolumn{2}{c}{ Protein (\%) } & \multicolumn{2}{c}{ Fat (\%) } \\
\cline { 2 - 8 } & Indoor & Outdoor & Indoor & Outdoor & Indoor & Outdoor & Indoor & Outdoor \\
\hline Mola & 10.59 & 10.20 & 10.02 & 10.05 & 65.58 & 66.51 & 10.98 & 11.14 \\
Chapila & 12.45 & 11.97 & 11.31 & 12.18 & 71.26 & 72.26 & 10.76 & 11.28 \\
Lal & 11.89 & 10.75 & 15.89 & 16.07 & 60.97 & 62.02 & 10.17 & 12.32 \\
Khailsha & & & & & & & & \\
\hline
\end{tabular}

It was evident that, all fishes were enriched to high protein and fat value after drying and there were no noteworthy variances in case of indoor and outdoor drying process.

While analyzing the acceptance and taste of the experimental fishes, result from consumers of ten different regions have been considered. The consumption technique as well as cooking procedure and demand on dried fish have been considered in this regard. The status of consumer's preference is given in Table 4. It has been observed that, $100 \%$ consumer acceptance have achieved in Chittagong, Lakshmipur, Mymensingh, Rangpur, Bandarban, Pabna and Sylhet districts. By analyzing the high acceptable label, it is found that, in Chittagong and Lakshmipur district, diversified fish is available. So, after full filling their live fish demand, people of that area preserve the surplus fishes by drying and 
as a result they become habituated by dry fish consumption. Thus, ultimately the sampled fish have been accepted by the consumers of these areas.

Table 4. Consumer's acceptances considering consumers from ten districts

\begin{tabular}{|c|c|c|c|}
\hline District & $\begin{array}{c}\text { Preference } \\
\text { at a scale of } \\
10\end{array}$ & Preference & $\begin{array}{c}\text { Comment } \\
\text { Dependency based preference }\end{array}$ \\
\hline Chittagong & 10 & $100 \%$ & $\begin{array}{l}\text { Marine fish plentiful and people preserve fish } \\
\text { by drying. }\end{array}$ \\
\hline Chandpur & 0 & $0 \%$ & $\begin{array}{l}\text { Variety of fish is present in this area, but } \\
\text { consumer preference is nil in case of dry fish. }\end{array}$ \\
\hline Lakshmipur & 10 & $100 \%$ & $\begin{array}{l}\text { Diversified fish available and extremely } \\
\text { preferred by consumers. }\end{array}$ \\
\hline Barisal & 0 & $0 \%$ & $\begin{array}{l}\text { A wide variety of fish is present, but } \\
\text { consumer prefer live fish. }\end{array}$ \\
\hline Mymensingh & 10 & $100 \%$ & $\begin{array}{l}\text { In this region, dry fish appeal a high demand } \\
\text { along in the form of Shidol. }\end{array}$ \\
\hline Rangpur & 10 & $100 \%$ & $\begin{array}{l}\text { Dry fish is highly accepted among the } \\
\text { individuals of this area. }\end{array}$ \\
\hline Bandarban & 10 & $100 \%$ & $\begin{array}{l}\text { Shidol is highly preferred sideways normal } \\
\text { sun-dried fish by the community of this area. }\end{array}$ \\
\hline Kushtia & 6 & $60 \%$ & $\begin{array}{l}\text { The consumers of this zone are used to live } \\
\text { fish consumption basically, but developed } \\
\text { their preference on dry fish as well. }\end{array}$ \\
\hline Pabna & 10 & $100 \%$ & $\begin{array}{l}\text { People used to dry fish in small scale, but } \\
\text { highly fond of dry fish. }\end{array}$ \\
\hline Sylhet & 10 & $100 \%$ & Dry fish is very popular in this district. \\
\hline
\end{tabular}

Beside this fact, it has been found in this study that, the background behind high acceptability of the trialed fish among the community of Mymensingh and Bandarban area might be that, they are very fond of dry fish and more or less keeps dry fish as an item in their daily meal. These people love to cook dry fish with vegetables. A very prominent feature of these people is that, they prefer to consume dry fish as a different form called "Shidol" which is a fermented form of dry fish. Therefore, the experimented fish was very well appreciated and marked highest by those consumers.

Alongside, wthout having any correlation with high fisheries resource and fish preservation technique, in case of Pabna and Rangpur district, these people in general are very affectionate about dry fish. So, these consumers appraise the tried fish very highly. On the other hand, in spite of having plentiful freshwater fish resource, the people of Sylhet rarely made dry fish, but appreciated the sample fish extremely.

It was found in the research that, in case of consumer acceptance of Barisal and Chandpur district, the experimental fish has been completely rejected, whereas achieved a $60 \%$ scale in case of the consumers of Kushtia. By analyzing the reason of such result, it was found that, the people of these three 

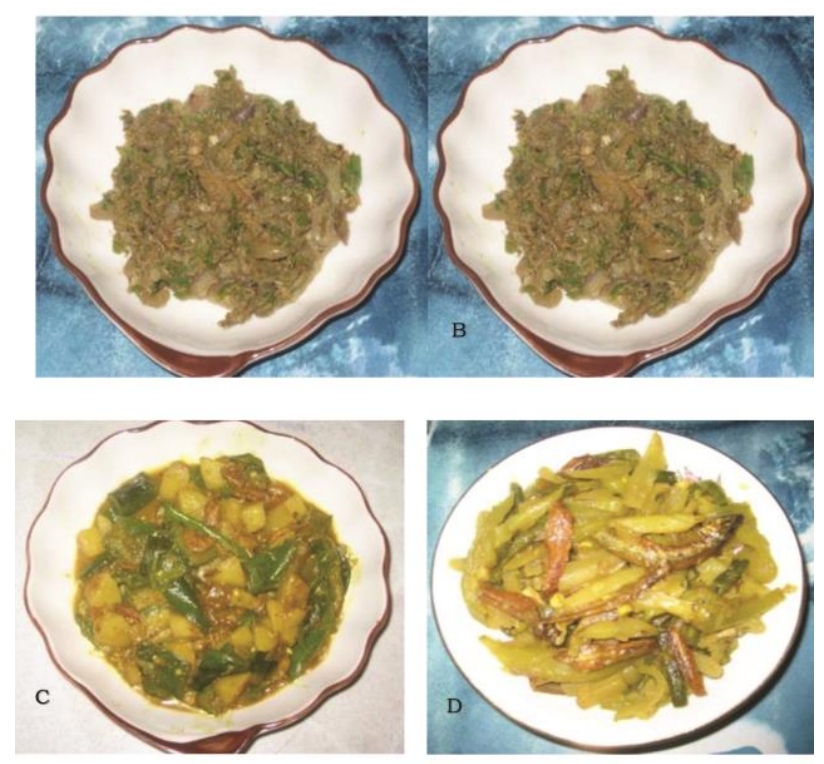

Fig. 3: a. Experimental fishes cooked by consumers of Lakshmipur. b. The trialed fish in the form of 'vorta' prepared by the consumers of Chittagong. c. Consumers of Mymensingh district tried the supplied dried fishes with several vegetables. d. The experimental Mola cooked in curry form using seasonal vegetables by the consumers of Sylhet.

places love to consume fish in live condition more than in dried form. Results of the present investigation revealed that, small scale drying in indoor high-rise apartment veranda and outdoor roof top condition do not show any prominent vitiation $(\mathrm{p}<0.05)$, either in drying time or fish quality. Furthermore, while analyzing the acceptance and taste of the experimental fishes, the people's perception was found to vary with their cultural background and fish-eating habits.

\section{CONCLUSION}

In conclusion it can be stated that, the present work had been conducted to produce good quality dry fish in urban high-rise state in complete natural process without any pesticide or chemical. In this regard, it is found that, not only the process was feasible enough, but also the dried fish contented high protein value and accredited by consumers regarding taste. So, this research can be beneficial enough to produce good quality dry fish in inner-city high-rise apartment.

\section{LITERATURE CITED}

CHAITY, F. N. 1992. A comparative study of the traditional dried and solar tent dried fresh water fishes of Bangladesh (M. Sc. Thesis). Department of Fisheries Technology, Bangladesh Agriculture University, Mymensingh, Bangladesh, 46-48pp. 
CONNELL, J. J. 1957. Some quality aspects of the texture of dehydrated fish. J. Sci. Food Agric., 8(9); 326-537 pp.

CLUCUS, I.J. and WARD, A. R. 1996. Post-harvest Fisheries Development: A Guide to Handling, Preservation, Processing and Quality. Chatham Maritime, Kent ME4 4TB, UK, 443 p.

CUTTING, C. L., REAY, G. A. and SHEWAN, J. M. 1956. Dehydration of fish. HMSO, London.

DOF, 2016-17. Yearbook of Fisheries Statistics of Bangladesh, Fisheries Resources Survey System, Dept of Fisheries, MOFL, GoB, 68.

DOF, 2017-18. Yearbook of Fisheries Statistics of Bangladesh, Fisheries Resources Survey System, Dept of Fisheries, MOFL, GoB, 74.

DOE, P. E., AHMED, M., MUSLEMUDDIN, M and SACHITHANANTHAN, K. 1977. A polythene tent drier for improved Sun drying of fish. Food Technology in Australia, 29; 437-441 pp.

DOHA, S. 1964. Fish and Shell fish preservation by sun or air drying in some selected countries and the problem involved. Journal 1-Fd. Agriculture council. Pakistan. XV (4): 455-477 pp.

KAMRUZZAMAN, A. K. M. 1992. Quality evaluation of some commercial dried fish products of Bangladesh (M. Sc. Thesis), Department of Fisheries Technology, Bangladesh Agriculture University, Mymensingh, Bangladesh, 34-38 pp.

LOVE, R. M. 1970. The Chemical Biology of Fishes, Academic Press, London and NY, 547 pp.

RAHMAN, A. K. A., 2005. Freshwater Fishes of Bangladesh, $2^{\text {nd }}$ edn., Zoological Society of Bangladesh, Dept of Zoology, DU, Dhaka, 394 p.

SAHA, S. C. 1999. Studies on production, marketing and nutritional aspects of traditional dried products of Bangladesh. (M. S. Thesis). Department of Fisheries Technology, Bangladesh Agriculture University, Mymensingh, Bangladesh. 62 pp.

WATERMAN, J. J. 1976. The production of dried fish. FAO Fisheries technical paper, Rome, 16; 1$52 \mathrm{pp}$.

ZAITSEV, V., KIZEVETTER, I., LAGUNOV, L., MAKAROVA, T., MINDER, L., and PODSEVALOV, V., 1969. Fish Curing and Processing (Translated from Russian by De Merindol) Mir Publishers, Moscow, 722 pp. 